\title{
Using Review Words for teaching vocabulary in collage
}

\author{
Haris Dibdyaningsih \\ English Education Department, STIKIP AL HIKMAH, Indonesia
}

\begin{tabular}{l}
\hline \hline Article Info \\
\hline Article history: \\
Received Jul 21, 2019 \\
Revised Aug 28, 2019 \\
Accepted Sept 23, 2019 \\
\hline
\end{tabular}

Keywords:

Review Words; Vocabulary.

\begin{abstract}
Review words is type of vocabulary building which is the easiest way to checking how is the students' understanding dealing with the previous vocabulary given, especially for college students. Classroom observation research was used as the method in this study. The method is divided into some stages namely review, reduce, recycle, vocab college, role reversal, word soup, and vocab box. It is a method of straightly observing teaching process, which the observer taking notes, and/or coding instructional performances in the classroom or from recorded activities or lesson. It is going to define some steps that we need to apply the review words. Moreover, it is still important to upgrading collage students' vocabulary because English as EFL will be very difficult term to reach when they are not seriously concern about the vocabulary. This paper will discuss the importance of using review words in checking students understanding in the certain level of English skill.
\end{abstract}

Copyright (ㅇ 2019 Department of English Teaching. All rights reserved.

\section{Corresponding Author:}

Haris Dibdyaningsih

English Education Department, STKIP AL Hikmah, Indonesia

Email: harisdibdyaningsih@gmail.com

\section{Introduction}

The most problems of students in studying English in EFL is when they cannot understand some words or a word that they meet while they are reading in a text. Some of them are eagerly to find it in the dictionary or other sources, but some of them get desperate with the word and give up to continue the text. As the teacher delivered the text to guide the students about new information and he/she wish that the students will get something new from the text. But, unfortunately most of the students give up to continue the text because they cannot understand the some of the words in text.

The teacher should try other way of teaching to make the students understand more vocabulary. In the other hand, teachers need to know well the level of the students' vocabulary so he/she will not make mistake in categorizing the students' vocabulary level. One of the most important things is how to improve and checking their vocabulary. Review words is one of the ways of checking students' understanding. We have to check, whether review words are able to show how is students' understanding.

The importance of vocabulary is very clear. When we get some difficulties in understanding a text it means that we need to improve our vocabulary. So, the basic thing that we should master in studying language is its vocabulary. We have to know the vocabulary before the grammar indeed. It is also stated in McCarty (2010) that vocabulary is everything about words, we use words all the time when we study a language, we have to study the vocabulary.

Nowadays, most of students like to have interactive media during the class, otherwise they like to have their own activity and ignore the lecture. So, lecture should find an interactive media which can trigger students to involved in the course happily. An interactive media which can be applied in the vocabulary class is review words, it is an activity that can help lecture in knowing the students' understanding of the vocabulary. It also helps the lecture to checking the students' vocabulary level. Wright, Betteridge and Buckby (2005) stated that language learning is very difficult and efforts are required over a long period of 
time. Special attention is given to the problems related teaching and learning vocabulary.

Based on the previous explanation, it can be concluded that vocabulary is one of the most powerful weapons for students to understand the new language. It also refers to that when students lack of vocabulary they will lack of understanding in many perspectives of English. Sometimes, students know the word in a context but they do not know the other meaning of the same word in another context of sentence. In addition, a review word on the importance of innovating interactive media to make language learning enjoyable and trigger students to apply their creativity is provided. Learners of new language have to deal with unfamiliar vocabulary during their acquisition. In order to learn and retain new words, learners should participate in different task-based activities in their classroom whether it is interactive game, describing things, memorizing task and conversation exercise. Such activities also include vocabulary building media which especially focus on helping learners develop and use words in different contexts by making the class enjoyable.

Therefore, it is necessary to explore whether students learn vocabulary effectively through review words and how they learn it. Normally students memorize the vocabularies in a list, and when they fail with this method, they will say that it is caused by their bad memorization. Research and publications have shown that this is not a very effective way to study. Ozmen (2004) expected to discuss a way of strengthening the awareness and through learning and self - esteem in adult language classes. 'Magic Box' is designed to help students built their self- esteem.

\section{Method}

Classroom observation research was used as the method in this study. The method is divided into some stages namely review, reduce, recycle, vocab college, role reversal, word soup, and vocab box. It is a method of straightly observing teaching process, which the observer taking notes, and/or coding instructional performances in the classroom or from recorded activities or lesson. This method involves the steps namely: 1) The pre-observation briefing. It is merely to know what an observer will be focusing on during the class. In this case it is the application of Evernote in writing; 2) Classroom observation. During the class, an observer make notes based on the items discussed at pre-review briefing; 3) The post-review de-briefing. It is better to conduct this step only within a few days of the class observation to keep the information still well remembered. 4) The final report.

\section{Result and Discussion}

Learning vocabulary can be facilitating by many different tools. One of the learning tools that is used in STKIP AL HIKMAH is 'review words' that seems have positive effects on learners' vocabulary learning. Thus, this study was conducted to identify how 'review words' may facilitate the teaching process and help students to learn vocabulary. And it has tried to find out whether 'review words' can improve learners' vocabulary learning process as well as identifies the potentiality of using 'review words' for creativity training.

The lectures can use it as alternatives way in teaching vocabularies. The lecture should try to have this activity in order to make the students interesting to upgrade their vocabulary and ability in understanding the words based on the context. Nowadays, there are so many books / e-books which are talking about a 'review words'. Some of them can be purchased in both conventional and online stores, while the online version can be subscribed. Furthermore, lectures are should be not worries about the material of review words that we can download freely in several website. Gerry Luton's website (http://www.englishvocabularyexercises.com/general-vocabulary/) is one of those which are free. In this website, we can download many exercises of vocabularies.

Moreover, we also may develop some activities that can trigger student's vocabularies awareness. Based on Benwell (2017), There is vocabulary activities which is very easy and potentially make the students interesting to study more vocabularies, it can be called as one-to-one vocabulary review actives. Here is some ideas of review word activity.

a. After the students learns a new word, work together to come up with 5 Wh-questions that relate to it.

Example : 'mock'.

Who mocks you a lot?

What do people mock teachers for? 
Where do people often mock?

When is mocking essential?

When is mocking rude?

How do you mocking politely?

b. Reduce, Reuse, Recycle

Choose 15 words from a reading that you are working on. Work together to write a story, poem, or letter that uses all of the new words. You could write it like a chain, where your student writes one sentence (and crosses off a word) and you write the next.

\section{c. Vocab Collage}

1) Bring in some old newspaper or magazines and have your student cut out objects and large words that he or she is familiar with in English.

2) While your student is making a familiar word, point to useful words and objects in a magazine that your student may not know. If your student does not know the word, cut the picture or word out and make your own with the unfamiliar words.

3) Go over the word collection regularly until your student knows all of the vocabulary. Try to use a balance of words and pictures to make the collection visually appealing. Vocab collections can be done in themes or just as a random vocabulary building activity that will also get your student talking.

\section{d. Role Reversal}

Teaching is the best way to learn. Tell your student to pretend that you are the learner. Your student will have to use examples, definitions, and drawings to get you to guess words from a list of new words.

\section{e. Word Soup}

1) Build Word Soup by focusing on themes or word forms. Draw a bowl on a piece of paper or on a board. Slowly call out related words and have your student write them in the bowl. Then call out a word that doesn't belong (e.g., vacuum cleaner). If your student detects the odd word, have him to start a new Word Soup beginning with this word. If your student doesn't spot the word, keep going for a while and then ask your student to spot the odd ingredient.

2) Get your student to create a big Word Soup before writing a word that doesn't go into it. You could do this with themes or with word forms (e.g., Verbs, Adjectives). For odd words, choose words that go with other word sets you have studied in the past. Make notes of the spelling mistakes and review them with your student.

\section{f. Vocabulary Box}

1) As you introduce new vocabulary, try to collect items that represent or relate to the new words. These can be actual items or pictures or objects that relate to the words. Put the items in a box or bag and look through it at the beginning or end of a lesson. Can your student remember why each item or picture is in the Vocabulary Box?

2) You can also use the Vocabulary Box for other activities such as writing poems or spelling quizzes. It may even come in convenient when you need game pieces for a board game.

Moreover, Decarrico (2001) mentioned that words should not be learnt separately or by memorization unless those were understood. Moreover, "learning new words is a cumulative process, with words enriched and established as they are met again", Nation (2000, p.6). Therefore, 'look and memorize' method of learning vocabulary seems not efficient for learn new language. Moreover, some of students still need their lecture to explain and give real example how to use the words. They may use words they learn in the exact formats as the original patterns in which those words appeared. This kind of rote verbal memorization is good to a certain extent since it helps learners learn and use the correct form of words.

However, according to Decarrico (2001), the vocabulary used in such context is rather simple because grammatical and phonologic aspects are emphasized; and as a result, the lexical aspect is neglected. In other words, learners just know how to use the vocabulary in an exact form, but they do not know how to use it with different shades of meanings in real life communication. In summary, 'Magic Box' as a teaching tool that helps students to create interactive media is very useful. It can improve student's vocabulary skill while improve their creativity too. 


\section{Conclusion}

The use of review words for teaching vocabulary offers many of advantages. That is why it is recommended that lectures try to apply of this way as their alternative's material in teaching vocabulary. They also may ask their students to choose and decide their own style of review words activities. The students are allowed to divine which activities are suitable for them in divining some words based on the context of the sentences. Since review words are available not only in hard copy but also in the soft file, lectures can also teach of how students can increase their vocabulary from vocabulary game in the internet. It also can help them in understanding new vocabularies by such kind of interesting materials through online vocabulary games. When students are conquering Vocabulary, it can be said that they have conquering the language.

\section{Refernces}

Benwell, Tara., (2017). One-to-One Vocabulary Review Activities. Retrieved from https://esllibrary.com/blog/one-to-one-vocab-review

Decarrico, J. S., (2001). "Vocabulary Learning and Teaching" in M. Celce-Murcia (ed.) (2001) Teaching English as a Second or Foreign Language ( $3^{\text {rd }}$ ed), Heinle \& Heinle: Boston, 285 300 .

Luton, Gerry., (2019). English Vocabulary Exercises. Retrieved from http://www.englishvocabularyexercises.com/contact.html

McCarthy, Michael, Anne O'Keeffe and Steve Walsh. (2010). Vocabulary Matrix. In Croatia (Ed.). A guide to citation rules (pp. 1-2). Retrieved from https://vk.com/doc806777_476578272?hash=659b048fed220bfedf\&dl=e39234f1534c6e6f1d

Nation, I.S.P., (2000). Learning Vocabulary in Another Language, $\quad$ Cambridge University Press: Cambridge.

Ozman, K. (2004) . "Make them Be Aware, Not Beware of learning" Asian EFL Journal. File:///Cl/asian-efl- journal/asianefljournal/04- kso.html

Skjåk, K. K., \& Harkness, J. A. (2003). Data collection methods. In J.A. Harkness, F. J. R. Van de Vijver, \& P. P. Mohler (Eds.), Cross-cultural survey methods (pp. 179-193). Hoboken, NJ: John Wiley \& Sons.

Wright, A., Betteridge, D., \& Buckby, M. (2005). Games for language learning (3rd ed.). New York: Cambridge 